\title{
Correction to: Compositional Changes in Foliage Phenolics with Plant Age, a Natural Experiment in Boreal Forests
}

\author{
Hilde Karine Wam ${ }^{1}$ - Caroline Stolter ${ }^{2} \cdot$ Line Nybakken ${ }^{3}$
}

Published online: 13 October 2017

(C) The Author(s) 2017. This article is an open access publication

\section{Correction to: J Chem Ecol \\ https://doi.org/10.1007/s10886-017-0881-5}

The article Compositional Changes in Foliage Phenolics with Plant Age, a Natural Experiment in Boreal Forests, written by Hilde Karine Wam, Caroline Stolter and Line Nybakken, was originally published electronically on the publisher's internet portal (currently SpringerLink) on August 29, 2017 without open access.

With the author(s)' decision to opt for Open Choice the copyright of the article changed on September 2017 to (C) The Author(s) 2017 and the article is forthwith distributed under the terms of the Creative Commons Attribution 4.0

International License (http:/creativecommons.org/licenses/ by/4.0/), which permits use, duplication, adaptation, distribution and reproduction in any medium or format, as long as you give appropriate credit to the original author(s) and the source, provide a link to the Creative Commons license and indicate if changes were made.

Open Access This article is distributed under the terms of the Creative. Commons At tribution 4.0 International License (http:// creativecommons.org/licenses/by/4.0/)which permits unrestricted use, distribution, and reproduction in any medium, provided you give appropriate credit to the original author(s) and the source, provide a link to the Creative Commons license, and indicate if changes were made.

The online version of the original article can be found under https://doi. org/10.1007/s10886-017-0881-5.

Hilde Karine Wam

hilde.wam@nibio.no

1 Division of Forest and Forest Resources, Norwegian Institute of Bioeconomy Research (NIBIO), 1431 Ås, Norway

2 Department of Animal Ecology and Conservation, University of Hamburg, 20146 Hamburg, Germany

3 Faculty of Environmental Sciences and Natural Resource Management, Norwegian University of Life Sciences, 1432 Ås, Norway 